Teacher educators' approaches to teaching and the nexus with self-efficacy and burnout : examples from two teachers' universities in China

Cao, Yanling

2018

Cao , Y , Postareff , L , Lindblom-Ylänne , S \& Toom , A 2018 , ' Teacher educators' approaches to teaching and the nexus with self-efficacy and burnout : examples from two teachers' universities in China ', Journal of Education for Teaching , vol. 44 , no. 4 , pp. 479-495 . https://doi.org/10.1080/02607476.2018.1450954

http://hdl.handle.net/10138/321491

https://doi.org/10.1080/02607476.2018.1450954

unspecified

acceptedVersion

Downloaded from Helda, University of Helsinki institutional repository.

This is an electronic reprint of the original article.

This reprint may differ from the original in pagination and typographic detail.

Please cite the original version. 


\title{
TEACHER EDUCATORS' APPROACHES TO TEACHING AND THE NEXUS WITH SELF-EFFICACY AND BURNOUT: EXAMPLES FROM TWO TEACHERS' UNIVERSITIES IN CHINA
}

\author{
Yanling Cao*a, Liisa Postareff ${ }^{b}$, Sari Lindblom ${ }^{a}$ and Auli Toom ${ }^{a}$ \\ ${ }^{a}$ Centre for University Teaching and Learning (HYPE), Faculty of Educational Sciences, \\ University of Helsinki, Helsinki, Finland \\ ${ }^{\mathrm{b}}$ Department of Teacher Education, Faculty of Education, University of Turku, Turku, Finland
}

\section{ORCID}

Yanling Cao 0000-0001-9005-5184

Liisa Postareff 0000-0002-9134-1163

Sari Lindblom 0000-0001-7297-7433

Auli Toom 0000-0002-3261-3376

*Corresponding author.Email:yanling.z.cao@helsinki.fi 


\section{Abstract}

Teacher educators' approaches to teaching, and their experience of burnout and self-efficacy beliefs, are related to how they are able to facilitate student teachers' learning. In this study, 115 Chinese teacher educators responded to a questionnaire in 2015. Based on the previous study investigating the teacher educators' approaches to teaching, the present study explored how these approaches were related to their self-efficacy beliefs in teaching and burnout. Burnout was measured through inadequacy in teacher-student interaction and exhaustion subscales. The analyses revealed that a student-focused approach to teaching among teacher educators was positively related to their self-efficacy beliefs in teaching. Both student- and teacher-focused approaches to teaching were positively related to the educators' experience of inadequacy in teacher-student interaction. However, the study revealed no relationship between teacher educators' approaches to teaching and the experience of exhaustion. To prevent feelings of inadequate interaction with their students, pedagogical training should provide these teacher educators with efficient guidance on how to interact with student teachers. The present study provides new insights in the teacher educators' adoption of the student- and teacher-focused approaches to teaching.

Keywords: approaches to teaching; self-efficacy beliefs; burnout; teacher educators 


\section{Introduction}

Teacher educators contribute significantly to the development of student teachers towards becoming competent teachers (Koster et al. 2005). They interact with student teachers, create learning environments for them, and support student teachers' learning about teacher's work (Toom et al. 2017). Teacher educators need to be flexible with their approaches to teaching to adapt them to support student teachers' learning (Baeten et al. 2016). Approaches to teaching are combinations of teaching intentions and strategies (Postareff and Lindblom-Ylänne 2008; Trigwell, Prosser, and Taylor 1994). Furthermore, it is argued that teacher educators act as models for their students about how to teach through their own approaches to teaching (Lortie 1975; Lunenberg, Korthagen, and Swennen 2007). Though student teachers' approaches to teaching are affected by many variables, and they demonstrate reflective thinking and critical judgements before adopting the teaching for their future pupils, the student-activating learning environments and student-focused approach to teaching from the teacher educators lead the student teachers towards the student-focused approach in their own teaching (Struyven, Dochy, and Janssens 2010).

'Teaching about teaching' is one of the tasks that teacher educators undertake. As professionals of teaching and education, teacher educators engage in multiple pedagogical tasks (Koster et al. 2005; Smith 2011), and they need substantial knowledge and competency to fulfil their complex pedagogical roles (Celik 2011). Thus it is necessary to explore teacher educators' burnout and self-efficacy beliefs correlated to their demanding work (Nagra and Arora 2013). However, little research has focused on how teacher educators' self-efficacy beliefs and burnout are related to their approaches to teaching. Teacher educators reported an average degree of burnout (Brewer and McMahan 2003). Teachers suffering from burnout are more likely to experience negative emotions and poor teacher-student interaction (Grayson and Alvarez 2008). Perceived inadequacy in teacher-student interaction is positively related to teachers' intentions to leave the 
profession (Heikonen et al. 2016). Furthermore, burnout is related to a low level of self-efficacy (Skaalvik and Skaalvik 2007), which is another factor that influences teachers' motivation and teaching behaviour (Temiz and Topcu 2013).

It is necessary to explore how teacher educators apply their approaches to teaching to support their students' learning, and furthermore to determine the factors that may influence their preferences. As important elements which affect teacher educators' professional development and academic career, teacher educators' self-efficacy and burnout have been investigated. However, there exist only a small number of empirical studies on teacher educators' approaches to teaching and insufficient understanding of the associations with self-efficacy and burnout. Therefore, this study focuses on the approaches to teaching among teacher educators as well as their perceived selfefficacy and burnout.

\section{Teacher educators' approaches to teaching}

Trigwell, Prosser, and Taylor (1994) differentiated between the Information transmission/teacherfocused approach to teaching (ITTF) and the Conceptual change/student-focused approach to teaching (CCSF). The former sees teaching as knowledge transmission from teachers to students. The latter sees teaching as helping students develop their own understanding of knowledge. Some teachers apply a single approach to teaching, that is, either a purely teacher-focused or a purely student-focused approach. However, most teachers adopt a combination of both approaches, which results in dissonant approaches to teaching (Postareff et al. 2008; Stes and van Petegem 2012). Teachers are encouraged to adopt the student-focused approach to teaching, as it is more likely to encourage students to implement the deep approach to learning (Trigwell, Prosser, and Waterhouse 1999). Furthermore, university teachers with the student-focused approach tend to have positive 
emotions towards teaching, whereas university teachers with the teacher-focused approach are more likely to feel either neutral or negative about teaching (Postareff and Lindblom-Ylänne 2011; Trigwell 2012).

Studies on teacher educators' approaches to teaching are rare. Teacher educators perceived different kinds of roles in teaching: some teacher educators think themselves as transmitters in teaching and student teachers are receivers; other teacher educators believe themselves as facilitators and guiders to assist student teachers' active role in the learning process (Wan, Wong, and Zhan 2013). These perceptions of teacher educators are in line with the teacher-focused and student-focused approaches to teaching descripted above. Teacher educators face a complex issue that approaches to teaching are context-dependent and influenced by many factors. The tension between 'telling and growth' in teacher educators' teaching describes their dilemma regarding teaching for knowledge transmission on the one hand and teaching for student teachers' own development of understanding on the other (Berry 2004).

Teacher educators need to be flexible to adapt their approaches to teaching to different teaching context. The uniqueness of teaching in teacher education is that the focus of teaching is not just on what student teachers should know and believe about teaching, but more importantly on what student teachers actually do when they are teaching. The knowledge for teaching is practicebased that involves actual tasks and activities of teaching. Thus, the content of teaching about teaching is much more than just theories and knowledge about teaching and learning, because teacher educators offer student teachers opportunities to learn the actual interactive work of teaching (Ball and Forzani 2009). Teacher educators decompose the teaching practice into parts and identify the ones that are important for the student teachers to understand and help them to build the foundation of the teaching profession (Ball and Forzani 2009). Moreover, teacher educators model expert teaching to student teachers and allow them to learn to become teachers (Toom et al. 2017). Teacher educators need to help student teachers to generate a deeply personal form of 
transformation to reformulate their beliefs of teaching (Berry 2004). Student teachers enter their professional studies with prior experiences as learners, and they have well-settled beliefs about teaching that might be extremely hard to change (Berry 2004). A student-focused approach to teaching of teacher educators is more related to student teachers' employment of a deep approach to learning, which is more beneficial for student teachers' conceptual change and reconstruction of beliefs (Trigwell, Prosser, and Waterhouse 1999).

Some researchers argue that learners need to be responsible for their own learning process and thus the instruction in teacher education should be shifted from teacher-focused to studentfocused. Furthermore, teacher educators need competences to promote this shift (Lunenberg and Korthagen 2003; Toom et al. 2017). It is indicated that in terms of instructional practices, teacher educators are a distinct group of teachers within the higher education setting as they apply more various teaching methods and assessments than other university teachers and use student-focused teaching strategies more often (Goubeaud and Yan 2004). However, the change towards more student-focused approach to teaching is challenging and the contextual factors, such as the specific topic being taught and the particular student groups, influence teachers' application of approaches to teaching (Sadler 2012). Thus, studies on teacher educators' approaches to teaching are important as they reveal knowledge of teacher educators' practices in the particular teacher education context (Nilsson and Loughran 2012).

\section{Teacher educators' self-efficacy beliefs}

Self-efficacy beliefs have been shown to be related to teachers' approaches to teaching (Temiz and Topcu 2013). Teacher self-efficacy is defined as 'individual teacher's beliefs in their own ability to plan, organise, and carry out activities that are required to attain given educational goals' (Skaalvik 
and Skaalvik 2010). Teachers with high self-efficacy are more likely to set higher educational goals for themselves and their students, and expect their students to pursue personal development. Teachers with confidence about a good acquiring of subject knowledge in an area would approach their teaching with more of student involvement. They are more willing to engage in teacherstudent interaction during the teaching process and apply the teaching methods that stimulate students' engagement and motivation in learning (Guskey 1988; Pitkäniemi 2002; Temiz and Topcu 2013). In contrast, teachers with low self-efficacy tend to employ teacher-directed teaching methods and believe in controlling students rather than trust them (Pitkäniemi 2002; Swackhamer et al. 2009). It is also demonstrated that a strong sense of self-efficacy beliefs is more related to strong personal accomplishments, and less stress and depression (Bandura 1994). Studies have revealed that positive emotions enhance perceived self-efficacy, and negative emotions diminish it (Kavanaugh and Bower 1985).

Teacher self-efficacy is related to teachers' teaching practices and effectiveness (Taimalu et al. 2010). Furthermore, it also influences students' motivation and achievement through teachers' teaching practices, enthusiasm and commitment (Mojavezi and Tamiz 2012). Therefore, there have been studies focusing on teachers' self-efficacy beliefs and the effects on their teaching as demonstrated above. However, most of these studies were conducted with primary school teachers and general university teachers. The rare studies with teacher educators explored their self-efficacy on the general professional level and found a positive relationship between self-efficacy and professional commitment (Attri and Devi 2017; Velu and Nordin 2011). There is a need for studies about teacher educators' self-efficacy in teaching, and more specifically, to study to what degree their self-efficacy beliefs in teaching account for the way they approach their teaching. 


\section{Teacher educators' burnout}

A strong relationship has been found between teacher self-efficacy and burnout (Skaalvik and Skaalvik 2007). Teacher burnout is a serious occupational problem with three symptoms: exhaustion, cynicism and professional inadequacy (Pietarinen et al. 2013). One study on the relationship between the self-efficacy of classroom management and the three dimensions of burnout showed that emotional exhaustion influences perceived self-efficacy. The direction was reversed in the relationships between self-efficacy and the other two dimensions of burnout: perceived self-efficacy affected cynicism and professional inadequacy (Brouwers and Tomic 2000). Other studies have revealed that emotional exhaustion and cynicism are negatively related to teacher self-efficacy, and that the relationship between teacher self-efficacy and burnout may be mutual. On one hand, low teacher self-efficacy may lead to burnout: on the other hand, burnout may also affect teacher self-efficacy (Skaalvik and Skaalvik 2007; 2010).

A low level of teacher self-efficacy is connected to a high level of burnout which could impede teachers' teaching work. Teachers with burnout tend to have low self-evaluation of themselves and experience more negative emotions (McGeary and McGeary 2012). The negative aspects of burnout are related to teachers' low quality of teaching and poor reaction to their students' learning needs (Grayson and Alvarez 2008). This can lead to teachers' estrangement from their students and result in a negative relationship with them (Brouwers and Tomic 1999). Furthermore, teachers with burnout tend to apply teaching practices that are less related to students' development of conceptual application skills (Retelsdorf et al. 2010).

Research on teacher educators' burnout is scarce, although they accomplish demanding work in educating qualified future teachers (Koster et al. 2005). Besides the teaching role, teacher educators also work as researchers and developers of knowledge and curricula (Celik 2011). It is argued that university teachers' teacher-researcher role conflict could lead to their feelings of 
uncertainty, stress and dissatisfaction, further result in emotional exhaustion and depersonalization (Xu 2017). It is revealed that teacher educators experienced a moderate level of occupational stress and burnout, and that a moderate level of stress could improve their work (Brewer and McMahan 2003; Nagra and Arora 2013). Nonetheless, previous studies failed to explain how much burnout could influence teacher educators' teaching performance, more specifically, to what extent burnout is related to their preference towards the student-focused and teacher-focused teaching. It is also revealed that female teacher educators were more stressed than male teacher educators (Nagra and Arora 2013). However, the demographic factors explain little of the variance in teacher educators' burnout, and more studies are needed to explore teacher educators' burnout (Brewer and McMahan 2003). It is necessary to investigate this issue because the pursuit of becoming a qualified teacher educator could lead to burnout, which might have negative effects on teacher educators' well-being and professional development, and further influence student teachers' learning.

\section{Aims and research questions}

The present study focuses on the teacher educators, who take the responsibility for educating competent future teachers. The purpose is to investigate how teacher educators' self-efficacy and burnout are related to their approaches to teaching. More specifically, in ascertaining how selfefficacy and burnout predict approaches to teaching, the study aims to explore teacher educators' application of the student- and teacher-focused approaches in teaching. The specific research questions are:

(1) How are teacher educators' approaches to teaching related to their self-efficacy beliefs?

(2) How are teacher educators' approaches to teaching related to their burnout? 
(3) How do teacher educators' self-efficacy beliefs and burnout predict their approaches to teaching?

First, it is hypothesised that teacher educators' self-efficacy beliefs are positively related to the student-focused approach to teaching, and negatively to the teacher-focused approach. Second, it is assumed that teacher educators' burnout is negatively related to the student-focused approach to teaching and positively to the teacher-focused approach. The student-focused approach to teaching is related to teachers' positive emotions, and the teacher-focused approach to their negative emotions (Postareff and Lindblom-Ylänne 2011; Trigwell 2012). Furthermore, teachers' positive emotions enhance their self-efficacy beliefs, and negative emotions diminish them (Kavanaugh and Bower 1985). Teachers with burnout tend to experience a low level of self-efficacy beliefs (Skaalvik and Skaalvik 2007) in addition to negative emotions (McGeary and McGeary 2012).

\section{Methods}

\section{Research context: Teaching and teacher educators in China}

Teaching and learning in China is influenced by Confucius and Chinese traditional culture, and thus, has its own distinctive nature. For example, Watkins and Biggs's $(1996,82)$ 'paradox of the Chinese learner' explained that Chinese learners perceive memorisation and repetition as processes that lead to understanding and discovering new meanings, which indicates the deep approach to learning. This differs from the Western understanding of learning, in which memorisation and repetition are seen as elements of the surface approach to learning.

Our previous study explored Chinese teacher educators' approaches to teaching (Cao et al. forthcoming). Analyses revealed that similarly with the 'paradox' in Chinese learners' learning, 
Chinese teacher educators perceived information transmission as an element of the student-focused approach to teaching. While in the Western cultures it is included in the teacher-focused approach. It indicates how Chinese teacher educators' approaches to teaching may be related to their understanding of student learning, and therefore differentiated from the Western understanding.

Our previous study (Cao et al. forthcoming) identified that most Chinese teacher educators adopted the student-focused approach to teaching. However, one group of teacher educators had a vague approach to teaching, as they showed no preference for either the teacher-focused or the student-focused approach. It is argued that although a majority of Chinese teacher educators adopt more student- than teacher-focused approaches to teaching, they encounter barriers to doing so, such as the pressure of institutional academic evaluation (Zhu 2010). However, with the reform of Chinese basic education and the demands of qualified school teachers, the research on teacher educators at universities and how they facilitate student teachers to become competent teachers is important (Li 1999).

\section{Participants}

The study involved two teachers' universities in North-Eastern part of China. One university is under the direct administration of the Ministry of Education, China, and represents high quality teacher education in China. Another one is a key university of the province in the same area as the former one. The 115 teacher educators (response rate 51\%) were from either the faculty of education or teacher-education programmes in other faculties at these two teachers' universities. Sixty-three participants were female (54.8\%), 49 were male (42.6\%) and three did not report their gender (2.6\%). The ages of the participants varied from 26 to 54 years $(M=39 ; \mathrm{SD}=6.42)$. Their teaching experience was between one and 33 years $(\mathrm{M}=13 ; \mathrm{SD}=7.66)$. Twenty of the participants $(18 \%)$ were early career teacher educators with teaching experience of five years or less. Three- 
quarters of the participants $(n=86)$ reported that they had pedagogical training, which varied from three days to 12 months $(\mathrm{M}=1.91$ months, $\mathrm{SD}=2.21)$. Of these, 61 teacher educators $(74.4 \%)$ had training of one month or even less. Twenty-six teacher educators $(22.6 \%)$ had no pedagogical training, and three provided no information on their pedagogical training.

\section{Measures and data collection}

The data were collected using an instrument including 32 items. First, teacher educators' approaches to teaching were investigated using the revised version of Approaches to Teaching Inventory (ATI-R; Trigwell, Prosser, and Ginns 2005), in which 11 items measure the teacherfocused approach to teaching, another 11 items measure the student-focused approach.

Second, four items, developed by Trigwell, Ashwin, and Lindblom-Ylänne, were used to explore teacher educators' self-efficacy beliefs in teaching (Lindblom-Ylänne et al. 2006). These items were adapted for measuring teachers' self-efficacy from items measuring students' selfefficacy in learning (Pintrich, Smith, and McKeachie 1989; Table 1).

\section{(Table 1 about here)}

Third, teacher educators' burnout was measured using six items of the Socio-contextual Teacher Burnout Inventory (STBI; Pietarinen et al. 2013). The STBI consists of nine items on three scales: exhaustion, cynicism towards the teacher community and inadequacy in teacher-student interaction, with three items on each respective scale. As the present study focuses on exploring teacher educators' approaches to teaching, the authors only applied six items from the exhaustion and inadequacy in teacher-student interaction scales (Table 2). 29 items regarding approaches to teaching, self-efficacy and inadequacy in teacher-student interaction were measured using a five- 
point Likert scale ranging from ' $1=$ only rarely or never true' to ' $5=$ almost always or always true'. Two items of exhaustion were measured using a seven-point Likert scale and the single item regarding stress on the exhaustion scale was measured on a 10-point scale, as in the scales applied in the original questionnaire (Elo, Leppänen, and Jahkola 2003; Pietarinen et al. 2013).

\section{(Table 2 about here)}

The Chinese version of the ATI-R had been translated by a Chinese researcher and was used in our previous study (Cao et al. forthcoming). Other items were translated into Chinese by the first author of the present study. Some changes in terminology were made to make the questionnaire correspond to the specific research context. Afterwards, the Chinese translation was back-translated into English by two scholars. The original English version and the back-translated one were very similar, with only minor differences, which were not considered as affecting the meanings of the items. The items were revised according to these differences.

The questionnaire was sent to the participants in 2015. The instructions to the questionnaire informed the respondents about the aims of the study and that the submission of the questionnaire was voluntary. Before answering the questionnaire, the participants were asked to think of a specific course and give a short description of the teaching situation.

\section{Data analyses}

First, exploratory factor analyses (principal axis factoring with Promax rotation) and reliability analyses (Cronbach's alpha) were conducted on the self-efficacy and burnout scales. The teacher educators' mean scores on these scales were calculated. Furthermore, the relationship between approaches to teaching, and self-efficacy and burnout were explored with correlation analysis. Next, 
one-way ANOVA was applied to explore the differences in the self-efficacy and burnout of the three clusters of teacher educators that were identified in our previous study (Cao et al. forthcoming). Since the variance homogeneity assumption was violated, the Dunnett T3 post hoc test method was used to detect the differences between the specific groups (Shingala and Rajyaguru 2015). Finally, multiple regression analyses were conducted to explore how self-efficacy and burnout could predict approaches to teaching.

In our previous study, the exploratory factor analysis of the ATI-R (Trigwell, Prosser, and Ginns 2005) showed that the factor structure of the inventory slightly differed from the original one presented by its developers (Cao et al. forthcoming). Two items were left out, and three items about teachers presenting information to the students loaded from the ITTF scale to the CCSF scale. Finally, the CCSF scale had 13 items with a Cronbach's Alpha of .86, and the ITTF scale had seven items with a Cronbach's Alpha of .72 (Appendix A).

Afterwards, a two-step cluster analysis identified three clusters of teacher educators (Figure 1). These results were used in the present study to analyse how approaches to teaching are related to teacher educators' self-efficacy and burnout. Cluster 1 had similar scores on the student- and teacher-focused approaches, and was thus named Teacher educators with a vague approach. Teachers in Cluster 2 had high scores on both approaches, and were labelled Teacher educators with a dissonant approach. Teachers in Cluster 3 emphasised the student-focused approach and were thus named Teacher educators with a student-focused approach. On the CCSF scale, Cluster 2 and Cluster 3 had similar scores, which were statistically significantly higher than those of Cluster 1. On the ITTF scale, Cluster 2 scored the highest, while Cluster 3 scored the lowest, and Cluster 1 had moderate scores. The differences between their scores were statistically significant.

(Figure 1 about here) 


\section{Results}

Teacher educators' self-efficacy and burnout

Exploratory factor analyses showed that on the self-efficacy scale, one factor was extracted with a Cronbach's Alpha of .85. On the burnout scale, two factors were extracted, inadequacy in teacherstudent interaction and exhaustion, with Cronbach's Alphas of .72 and .69, respectively. Because of the small sample size and the small number of items per scale, the scales were considered usable.

Afterwards, the means and standard deviations of teacher educators' self-efficacy and burnout were calculated (Table 3). Since the stress item on the exhaustion subscale of burnout was measured using a 10-point Likert scale, while the other two items on exhaustion were measured using a seven-point Likert scale, the mean of the single stress item were calculated separately.

\section{(Table 3 about here)}

The relationship between teacher educators' approaches to teaching, and self-efficacy and burnout were explored through correlation analysis. It revealed statistically significant positive relationships between the student-focused approach to teaching (CCSF) and self-efficacy, and between the teacher-focused approach (ITTF) and inadequacy. A statistically significant negative relationship between the student-focused approach and exhaustion was found. No relationship was shown between approaches to teaching and the single item of stress (Table 4).

(Table 4 about here) 
Self-efficacy and burnout of three different teacher educator groups

Based on our previous study in which the teacher educators were divided into three clusters (Cao et al. forthcoming), the teacher educators' mean scores of self-efficacy and burnout were calculated firstly according to these clusters (Table 5 and Figure 2).

(Table 5 about here)

(Figure 2 about here)

Afterwards, one-way ANOVA revealed statistically significant differences between the three clusters' mean scores on the self-efficacy scale $(\mathrm{F}=10.92, p<.001)$ and inadequacy in teacher-student interaction subscale of burnout $(\mathrm{F}=6.16, p=.003)$. No difference was shown on the exhaustion subscale of burnout.

The Dunnett T3 post hoc tests on the self-efficacy of the three clusters revealed that the teacher educators with a vague approach (Cluster 1) statistically significantly differed from the teacher educators with a dissonant approach (Cluster 2) and the teacher educators with a studentfocused approach (Cluster 3). However, there was no statistically significant difference between Cluster 2 and Cluster 3. On the inadequacy in teacher-student interaction subscale, Cluster 2 statistically differed from Cluster 1 and Cluster 3, no statistically significant difference was found between Cluster 1 and Cluster 3 (Table 6).

(Table 6 about here) 
Compared with the teacher educators with a vague approach (Cluster 1), other teacher

educators who had higher scores on the CCSF scale also scored higher on their self-efficacy beliefs. Teacher educators who scored higher on the ITTF scale also scored higher on inadequacy in teacher-student interaction.

\section{Relationship between approaches to teaching, and self-efficacy and burnout}

After exploring the differences in the self-efficacy beliefs and burnout of teacher educators with different approaches to teaching, multiple regression analyses were conducted to investigate how self-efficacy and burnout predict these approaches. On the CCSF scale, $41.7 \%$ of the total variance of the student-focused approach to teaching can be explained by self-efficacy beliefs, inadequacy, exhaustion and stress (adjusted $\left.\mathrm{R}^{2}=.417, \mathrm{~F}(4,110)=21.41, p<.001\right)$. Two predictor variables were statistically significant: self-efficacy and inadequacy, with standardised coefficients of .64 and .25 , respectively (Table 7 ).

\section{(Table 7 about here)}

On the ITTF scale, $12.1 \%$ of the total variance of the teacher-focused approach to teaching can be explained by the predictor variables (adjusted $\left.\mathrm{R}^{2}=.121, \mathrm{~F}(4,110)=4.94, p=.001\right)$. The statistically significant standardised coefficient of inadequacy in teacher-student interaction was .40 . Other standardised coefficients of the predictor variables were not statistically significant (Table 8).

\section{(Table 8 about here)}


The first hypothesis was partly supported because the analysis showed that the teacher educators' student-focused approach to teaching correlated positively with their self-efficacy. However, teacher educators' self-efficacy beliefs had an insignificant influence on their teacherfocused approach to teaching. As regards the second hypothesis, inadequacy in teacher-student interaction subscale of burnout had a positive relationship with both student- and teacher-focused approaches to teaching. Though in the correlation analysis, exhaustion had a statistically significant negative relationship with the student-focused approach to teaching, while the multiple regression analysis revealed an insignificant influence from exhaustion on approaches to teaching. Thus, the second hypothesis was also partly supported.

\section{Discussion}

In line with a previous study, which indicated that teachers' self-efficacy may influence which teaching methods they applied (Temiz and Topcu 2013), our study revealed that teacher educators in the present study with different kinds of approaches to teaching differed in their self-efficacy beliefs in teaching. The more student-focused they were in their approaches to teaching, the stronger self-efficacy they had. Furthermore, multiple regression analysis showed that self-efficacy had the greatest and most positive influence on the student-focused approach to teaching. Thus, the relationship between the student-focused approach to teaching and self-efficacy might be reciprocal. Teachers with a strong sense of self-efficacy believe in their ability to teach and are more likely to engage in teacher-student interaction (Guskey 1988; Pitkäniemi 2002; Temiz and Topcu 2013). Similarly, teacher educators with a high level of self-efficacy might be confident in their teaching competencies and more willing to engage with student teachers in their teaching, promoting the students' own personal development. Moreover, teacher educators with the student-focused 
approach to teaching may strengthen their self-efficacy through helping their students in their personal development.

The ANOVA analysis showed a positive relationship between their teacher-focused approach to teaching and inadequacy in teacher-student interaction. Furthermore, multiple regression analysis indicated a positive influence from inadequacy on not only the teacher-focused approach to teaching, but also the student-focused approach. This suggests that the relationship between teacher educators' approaches to teaching and inadequacy in teacher-student interaction is complex. Previous studies have elaborated that teachers' positive emotions are positively related with their student-focused approach to teaching and student-focused teachers experience enthusiasm and enjoyment from teaching and feel strong empathy towards students (Postareff and LindblomYlänne 2011; Heikonen et al. 2016; Trigwell 2012). Thus, the student-focused teacher educators who are more motivated and enthusiastic about teaching, despite feeling ineffective in their interaction with their students, might have more positive attitudes towards developing this interaction, approach their teaching with a focus on their students, and interacting more with their students. Further, the more student-focused teacher educators are also more exposed to interaction with their students than the teacher-focused teacher educators. They might thus find interactive teaching-learning situations more challenging, and be more critical about their ability to create meaningful interactions with their students.

The negative emotions are positively related to the teacher-focused approach to teaching, and thus teacher-focused teachers tend to feel negatively about teaching and the development of teaching (Postareff and Lindblom-Ylänne 2011; Trigwell 2012). Thus, if teacher-focused teacher educators feel that their interaction with their students is inadequate, they may have a negative attitude towards improving this interaction, and focus more on themselves and the teaching content. This may further strengthen their teacher-focused approach. However, the reason for why teacher 
educators' inadequacy in teacher-student interaction is positively related to both student- and teacher-focused approaches to teaching is complicated, and requires further exploration.

\section{Methodological reflections}

The questionnaire included six items from the STBI (Pietarinen et al. 2013), which has been developed to detect teacher burnout in the school context, and has not been validated in any country other than Finland. In the present study, some changes to the terminology were made to make the six items suitable for the teacher education research context. Factor analysis and reliability analysis revealed that the scales were valid and reliable for measuring teachers' burnout in the current research context. The response rate of the study was 51\%. It is possible that the non-respondents were not as concerned about or interested in teaching as those who responded, the sample of the study might be biased.

Implications regarding the practice of teacher educators and future studies

It has been suggested that teacher educators should be encouraged to adopt gradually the studentfocused approach to teaching (Postareff, Lindblom-Ylänne, and Nevgi 2007; Saariaho et al. 2016; Toom et al. 2017; Trigwell, Prosser, and Waterhouse 1999). The present study showed that the sampled teacher educators' self-efficacy beliefs in teaching have a positive effect on their studentfocused approach to teaching and thus, strengthening self-efficacy beliefs could also serve as a means to support adoption of the student-focused approach to teaching. Chinese student teachers experience complex emotional feelings and ethical dilemmas in their identity formation during the teacher education study, it is necessary for teacher educators to be attentive to their students' confusions in the study (Zhu 2017). The communication and interaction between teacher educators 
and student teachers are helpful for student teachers. Moreover, it is revealed in the study that teacher educators' feelings of inadequate interaction with student teachers could lead to their application of the teacher-focused approach to teaching. Thus, instructions and examples on how to interact with student teachers and increase student teachers' participation as well as active role in teacher education courses would be helpful for teacher educators.

Previous studies have stressed the importance of professional development and pedagogical training programmes for university teachers. For example, university pedagogical courses are an effective way to develop teachers' approaches to teaching from teacher-focused to student-focused (Gibbs and Coffey 2004; Postareff, Lindblom-Ylänne and Nevgi 2007; 2008). The professional development programmes and pedagogical training could be arranged especially suitably to the Chinese teacher educators' teaching context and cultural background. Our previous study showed that Chinese teacher educators' perceptions of the teacher- and student-focused approaches to teaching could be related to the 'paradox' in their students' learning and the Chinese culture, thus differentiated from the traditional understandings in Western countries (Cao et al. forthcoming; Watkins and Biggs1996).

The present study showed that the teacher educators in the study had a high level of selfefficacy beliefs, a low level of inadequacy in teacher-student interaction and a moderate level of exhaustion. Moreover, it produced new knowledge on how Chinese teacher educators' self-efficacy and burnout influence their approaches to teaching, and highlights the importance of addressing self-efficacy and burnout during training programmes targeted for the Chinese teacher educators. Increasing their awareness of their own self-efficacy and burnout, and how these two factors relate to their own teaching development, could be of importance during the training programmes.

The study applied quantitative methodologies to improve the understanding of how teacher educators' approaches to teaching, self-efficacy and burnout are related to each other. Future research could be qualitative, to further explore the explanation of the positive correlations between 
inadequacy in teacher-student interaction and both the student- and teacher-focused approaches to teaching. Furthermore, teacher educators' self-efficacy and burnout could only explain little (12\%) of the variance of the teacher-focused approach to teaching, what kind of other factors account for the variance of the teacher-focused approach could be a start for new studies. Unfortunately, our study did not reveal how exhaustion could influence teacher educators' approaches to teaching. As an important dimension of burnout, further analysis should be conducted on teacher educators' exhaustion. Our present study explored the connections between Chinese teacher educators' approaches to teaching, and self-efficacy and burnout. However, more research on the variation in teaching and learning generated by cultural difference and more studies about Chinese teacher educators' teaching are needed to enrich the knowledge in this area and verify the results of our study.

\section{Disclosure statement}

No potential conflict of interest was reported by the authors.

\section{Funding}

This work was supported by the Chinese Scholarship Council. 


\section{References}

Attri, A. K., and N. Devi. 2017. "Relationship between Professional Commitment and Self-efficacy of Secondary Teacher Educators.' International Journal of Advanced Education and Research 2(4): 42-44.

Baeten, M., F. Dochy, K. Struyven, E. Parmentier, and A. Vanderbruggen. 2016. "Student-centred Learning Environments: An Investigation into Student Teachers' Instructional Preferences and Approaches to Learning.' Learning Environments Research 19: 43-62.

Ball, D. L., and F. M. Forzani. 2009. "The Work of Teaching and the Challenge for Teacher Education.'" Journal of Teacher Education 60(5): 497-511.

Bandura, A. 1994. "Self-efficacy." In Encyclopedia of Human Behaviour, edited by V. S. Ramachaudran, 71-81. New York: Academic Press.

Berry, A. 2004. "'Self Study in Teaching about Teaching.' In International Handbook of Self-study of Teaching and Teacher Education Practices, edited by J. J. Loughran, M. L. Hamilton, V. K. LaBoskey, and T. Russell, 1295-1332. Netherlands: Springer Netherlands.

Brewer, E. W., and J. McMahan. 2003. “'Job Stress and Burnout among Industrial and Technical Teacher Educators.' Journal of Vocational Education Research 28(2): 125-140.

Brouwers, A., and W. Tomic. 1999. “Teacher Burnout, Perceived Self-efficacy in Classroom Management, and Student Disruptive Behavior in Secondary Education.' Curriculum and Teaching 14(2): 7-26.

Brouwers, A., and W. Tomic. 2000. “A Longitudinal Study of Teacher Burnout and Perceived Selfefficacy in Classroom Management.' Teaching and Teacher Education 16: 239-253.

Cao, Y., L. Postareff, S. Lindblom-Ylänne, and A. Toom. Forthcoming. ' Teacher Educators' Approaches to Teaching and Connections with Research-teaching Nexus.",

Celik, S. 2011. "Characteristics and Competencies for Teacher Educators: Addressing the Need for Improved Professional Standards in Turkey.' Australian Journal of Teacher Education 36(4): 73-87.

Elo, A-L, A. Leppänen, and A. Jahkola. 2003. " Validity of a Single-item Measure of Stress Symptoms.' Scandinavian Journal of Work, Environment \& Health 29(6): 444-451.

Gibbs, G., and M. Coffey. 2004. "The Impact of Training of University Teachers on Their Teaching Skills, Their Approaches to Teaching and the Approaches to Learning of Their Students.' Active Learning in Higher Education 5(1): 87-100. 
Goubeaud, K., and W. Yan. 2004. 'Teacher Educators' Teaching Methods, Assessments, and Grading: A Comparison of Higher Education Faculty's Instructional Practices.' The Teacher Educator 40(1): 1-16.

Grayson, J. L., and H. K. Alvarez. 2008. "School Climate Factors Relating to Teacher Burnout: A Mediator Model."' Teaching and Teacher Education 24: 1349-1363.

Guskey, T. R. 1988. "Teacher Efficacy, Self, Concept, and Attitudes toward the Implementation of Instructional Innovation.’" Teaching and Teacher Education 4: 63-69.

Heikonen, L., J. Pietarinen, K. Pyhältö, A. Toom, and T. Soini. 2016. ' Early Career Teachers' Sense of Professional Agency in the Classroom: Associations with Turnover Intentions and Perceived Inadequacy in Teacher-student Interaction.' Asia-Pacific Journal of Teacher Education 45(3): 250-266.

Kavanaugh, D. J., and G. H. Bower. 1985. “Mood and Self-efficacy: Impact of Joy and Sadness on Perceived Capabilities.' Cognitive Therapy and Research 9(5): 507-525.

Koster, B., M. Brekelmans, F. Korthagen, and T. Wubbels. 2005. 'Quality Requirements for Teacher Educators."' Teaching and Teacher Education 21: 157-176.

Li, D. 1999. "Modernization and Teacher Education in China.', Teaching and Teacher Education 15: 179-192.

Lindblom-Ylänne, S., K. Trigwell, A. Nevgi, and P. Ashwin. 2006. "How Approaches to Teaching are Affected by Discipline and Teaching Context.' Studies in Higher Education 31(3): 285298.

Lortie, D. C. 1975. Schoolteacher: A Sociological Study. Chicago: The University of Chicago Press. Lunenberg, M., and F. Korthagen. 2003. "Teacher Educators and Student-directed Learning." Teaching and Teacher Education 19: 29-44.

Lunenberg, M., F. Korthagen, and A. Swennen. 2007. "The Teacher Educator as a Role Model." Teaching and Teacher Education 23: 586-601.

McGeary, C. A., and D. D. McGeary. 2012. “'Occupational Burnout.” In Handbook of Occupational Health and Wellness, edited by R. J. Gatchel, and I. Z. Schultz, 181-200. New York: Springer.

Mojavezi, A., and M. P. Tamiz. 2012. "The Impact of Teacher Self-efficacy on the Students' Motivation and Achievement.' Theory and Practice in Language Studies 2(3): 483-491.

Nagra V., and S. Arora. 2013. "'Occupational Stress and Health among Teacher Educators.', International Journal of Advanced Research in Management and Social Sciences 2(8): 1-13. 
Nilsson, P., and J. Loughran. 2012. "Developing and Assessing Professional Knowledge as a Science Teacher Educator: Learning about Teaching from Student Teachers.' In Self-study of Science Teacher Education Practices, edited by S. M. Bullock, and T. Russell, 121-138. Netherlands: Springer Netherlands.

Pietarinen, J., K. Pyhältö, T. Soini, and K. Salmela-Aro. 2013. "Validity and Reliability of the Socio-contextual Teacher Burnout Inventory (STBI).'” Psychology 4(1): 73-82.

Pintrich, P., D. A. F. Smith, and W. J. McKeachie. 1989. “A Manual for the Use of the Motivated Strategies for Learning Questionnaire (MSLQ)"' (Ann Arbor, MI, National Centre for Research to Improve Postsecondary Teaching and Learning, University of Michigan). Pitkäniemi, H. 2002. "The Relationship between Teacher Efficacy, Instructional Practice and Student Learning: How do They Relate to Each Other?' In Developing Teacher Education in Estonia, edited by K. Niinistö, H. Kukenilk, and L. Kemppinen, 127-140. Turku: Turun Yliopisto.

Postareff, L., N. Katajavuori, S. Lindblom-Ylänne, and K. Trigwell. 2008. " Consonance and Dissonance in Descriptions of Teaching of University Teachers.' Studies in Higher Education 33(1): 49-61.

Postareff, L., and S. Lindblom-Ylänne. 2008. "Variation in Teachers' Description of Teaching:

Broadening the Understanding of Teaching in Higher Education.' Learning and Instruction 18: 109-120.

Postareff, L., and S. Lindblom-Ylänne. 2011. "Emotions and Confidence within Teaching in Higher Education.'’ Studies in Higher Education 36(7): 799-813.

Postareff, L., S. Lindblom-Ylänne, and A. Nevgi. 2007. “'The Effect of Pedagogical Training on Teaching in Higher Education.' Teaching and Teacher Education 23: 557-571.

Postareff, L., S. Lindblom-Ylänne, and A. Nevgi. 2008. "A Follow-up Study of the Effect of Pedagogical Training on Teaching in Higher Education.'” Higher Education 56: 29-43.

Retelsdorf, J., R. Butler, L. Streblow, and U. Schiefele. 2010. "Teachers' Goal Orientations for Teaching: Associations with Instructional Practices, Interest in Teaching, and Burnout." Learning and Instruction 20: 30-46.

Saariaho, E., K. Pyhältö, A. Toom, J. Pietarinen, and T. Soini. 2016. ' Student Teachers' Self- and Co-regulation of Learning during Teacher Education.' Learning: Research and Practice 2 (1): 44-63.

Sadler, I. 2012. "The Challenges for New Academics in Adopting Student-centred Approaches to Teaching.' Studies in Higher Education 37(6): 731-745. 
Shingala, M. C., and A. Rajyaguru. 2015. "Comparison of Post Hoc Tests for Unequal Variance.' International Journal of New Technologies in Science and Engineering 2(5): 22-33.

Skaalvik, E. M., and S. Skaalvik. 2007. "Dimensions of Teacher Self-efficacy and Relations with Strain Factors, Perceived Collective Teacher Efficacy, and Teacher Burnout.' Journal of Educational Psychology 99: 611-625.

Skaalvik, E. M., and S. Skaalvik. 2010. "Teacher Self-efficacy and Teacher Burnout: A Study of Relations.' Teaching and Teacher Education 26: 1059-1069.

Smith, K. 2011. "The Multi-faced Teacher Educator: A Norwegian Perspective.' Journal of Education for Teaching 37(3): 337-349.

Stes, A., and P. Van Petegem. 2014. "'Profiling Approaches to Teaching in Higher Education: A Cluster-analytic Study.' Studies in Higher Education 39: 644-658.

Struyven, K., F. Dochy, and S. Janssens. 2010. "'Teach as You Preach': The Effects of Studentcentred versus Lecture-based Teaching on Student Teachers' Approaches to Teaching." European Journal of Teacher Education 33(1): 43-64.

Swackhamer, L. E., K. Koellner, C. Basile, and D. Kimbrough. 2009. “'Increasing the Self-efficacy of Inservice Teachers through Content Knowledge.' Teacher Education Quarterly 36(2): $63-78$.

Taimalu, M., E. Kikas, M. Hinn, and A. Niilo. 2010. “Teachers' Self-efficacy, Teaching Practices, and Teaching Approaches: Adaption of Scales and Examining Relations.' In Estonian Studies in Education, edited by J. Mikk, M. Veisson, and P. Luik, 122-137. Bern, Switzerland: Peter Lang D.

Temiz, T., and M. S. Topcu. 2013. 'PPreservice Teachers' Teacher Efficacy Beliefs and Constructivist-based Teaching Practice.' European Journal of Psychology of Education 28(4): 1435-1452.

Toom, A., J. Pietarinen, T. Soini, and K. Pyhältö. 2017. "How Does the Learning Environment in Teacher Education Cultivate First Year Student Teachers' Sense of Professional Agency in the Professional Community?'" Teaching and Teacher Education 63: 126-136.

Trigwell, K. 2012. “Relations between Teachers' Emotions in Teaching and Their Approaches to Teaching in Higher Education."' Instructional Sciences 40: 607-621.

Trigwell, K., M. Prosser, and P. Ginns. 2005. " Phenomenographic Pedagogy and a Revised Approaches to Teaching Inventory.' Higher Education Research and Development 24(4): 349-360. 
Trigwell, K., M. Prosser, and P. Taylor. 1994. "QQualitative Differences in Approaches to Teaching First Year University Science.' Higher Education 27: 75-84.

Trigwell, K., M. Prosser, and F. Waterhouse. 1999. ' Relations between Teachers' Approaches to Teaching and Students' Approaches to Learning.' Higher Education 37: 57-70.

Velu J., and M. B. Nordin. 2011. "Evaluating Measurement Model of Lectures Self-efficacy." 2011 International Conference on Management and Service Science 8: 140-144.

Watkins, D. A., and J. B. Biggs. 1996. The Chinese Learner: Cultural, Psychological and Contextual Influences. Hong Kong; Melbourne, Australia: Comparative Education Research Centre; Australian Council for Educational Research.

Wan, Z. H., S. L. Wong, and Y. Zhan. 2013. " Teaching Nature of Science to Preservice Science Teachers: A Phenomenographic Study of Chinese Teacher Educators' Conceptions.' Science \& Education 22: 2593-2691.

$\mathrm{Xu}$, L. 2017. "Teacher-researcher Role Conflict and Burnout among Chinese University Teachers: A Job Demand-resources Model Perceptive.' Studies in Higher Education. Advance online publication. doi:10.1080/03075079.2017.1399261

Zhu, H. 2010. "Curriculum Reform and Professional Development: A Case Study on Chinese Teacher Educators.' Professional Development in Education 36(1-2): 373-391. Zhu, G. 2017. 'Chinese Student Teachers' Perspectives on Becoming a Teacher in the Practicum: Emotional and Ethical Dimensions of Identity Shaping.' Journal of Education for Teaching 43(4): 491-495. 


\section{Appendix A. Scales of ATI-R (Cao et al. forthcoming)}

CCSF scale

3. In this course I try to develop a conversation with my students about the topics we are studying.

6. I set aside some teaching time so that the students can discuss, among themselves, key concepts and ideas in this subject.

8. I encourage students to restructure their existing knowledge in terms of the new way of thinking about the subject that they will develop.

10. In teaching sessions for this subject, I deliberately provoke debate and discussion.

17. I make available opportunities for students in this course to discuss their changing understanding of the subject.

18. It is better for students in this course to generate their own notes rather than copy mine.

23. I see teaching as helping students develop new ways of thinking in this subject.

24. In teaching this subject it is important for me to monitor students' understanding of the subject matter.

27. Teaching in this course should help students question their own understanding of the subject matter.

28. Teaching in this course should support students to find their own learning resources.

(Three items that were originally on the ITTF scale)

4. It is important to present a lot of facts to students so that they know what they have to learn for this subject.

21. In this course my teaching focuses on the good presenting information to students.

29. I present material to enable students to build up an information base in this subject.

ITTF scale

1. In this course students should focus their study on what I provide them.

2. It is important that the course is completely described in terms of specific objectives that relate to the assessment of the course.

7. In this course I concentrate on covering the information that might be available from key texts and readings.

11. I structure my teaching in this subject to help students to pass the assessment of the course.

13. I think it is important to give students a good set of notes in this course.

14. In this course, I provide the students with the information they will need to pass the formal assessments.

25. My teaching in this course focuses on delivering what I know to the students.

2 deleted items

15. I should know the answers to any questions that students may put to me during this course.

20. A lot of teaching time in this course should be used to question students' ideas.

\section{Tables}


Table 1. Items of teachers' self-efficacy beliefs and students' self-efficacy beliefs.

\begin{tabular}{l|l}
\hline Teachers' self-efficacy beliefs & Students' self-efficacy beliefs \\
\hline $\begin{array}{l}\text { 9. I am confident that my knowledge of this subject } \\
\text { matter is not a barrier to teaching it well. }\end{array}$ & $\begin{array}{l}\text { 1. I am confident that I can understand the most } \\
\text { complex material presented by the instructor in this } \\
\text { course. }\end{array}$ \\
$\begin{array}{l}\text { 16. I am certain that I have the necessary skills to } \\
\text { teach I amis course. }\end{array}$ & $\begin{array}{l}\text { in this class. } \\
\text { 3. I am confident I can learn the basic concepts taught } \\
\text { in this course. }\end{array}$ \\
$\begin{array}{l}\text { in this course. } \\
\text { 26. I am confident that my knowledge of teaching } \\
\text { is not a barrier to teaching well. }\end{array}$ & $\begin{array}{l}\text { material presented in the readings for this course. } \\
\text { main I can understand the most difficult }\end{array}$ \\
\hline
\end{tabular}

Table 2. Items of burnout.

Inadequacy in teacher-student interaction

5. Dealing with problem situations considering my students often upsets me.

12. The challenging students make me question my abilities as a teacher.

19. I often feel I have failed in my work with students.

Exhaustion

30. I feel burnt out.

31. With this work pace I don't think I will make it to the retiring age.

32. Stress means a situation in which a person feels tense, restless, nervous or anxious or is unable to sleep at night because his/her mind is troubled all the time. Do you feel this kind of work-related stress?

Table 3. Means and standard deviations of teacher educators on the two scales.

\begin{tabular}{|c|c|c|c|c|}
\hline & \multirow{2}{*}{$\begin{array}{l}\text { Teacher self-efficacy } \\
\text { (5-point Likert scale) }\end{array}$} & \multicolumn{3}{|c|}{ Teacher burnout } \\
\hline & & $\begin{array}{l}\text { Inadequacy } \\
\text { (5-point Likert } \\
\text { scale) }\end{array}$ & $\begin{array}{l}\text { Exhaustion } \\
\text { (7-point Likert } \\
\text { scale) }\end{array}$ & $\begin{array}{c}\text { Stress } \\
\text { (10-point Likert } \\
\text { scale) }\end{array}$ \\
\hline $\mathrm{M}$ & 4.28 & 1.82 & 3.05 & 5.01 \\
\hline SD & .70 & .89 & 1.61 & 2.82 \\
\hline
\end{tabular}


Table 4. Correlations of approaches to teaching, and self-efficacy and burnout.

\begin{tabular}{llcccccc}
\hline & & \multicolumn{2}{c}{$\begin{array}{c}\text { Approaches to } \\
\text { teaching }\end{array}$} & Self-efficacy & \multicolumn{3}{c}{ Burnout } \\
& & CCSF & ITTF & & Inadequacy & Exhaustion & Stress \\
\cline { 3 - 8 } & & $\mathrm{R}$ & $\mathrm{R}$ & $\mathrm{R}$ & $\mathrm{R}$ & $\mathrm{R}$ & $\mathrm{R}$ \\
\hline Approaches & CCSF & - & -.08 & $.49^{* *}$ & -.08 & $-.30^{* *}$ & -.13 \\
to teaching & ITTF & -.08 & - & -.03 & $.33^{* *}$ & .11 & .03 \\
Self-efficacy & & $.49^{* *}$ & -.03 & - & $-.43^{* *}$ & $-.22^{*}$ & .00 \\
& Inadequacy & -.08 & $.33^{* *}$ & $-.43^{* *}$ & - & $.28^{* *}$ & .12 \\
Burnout & Exhaustion & $-.30^{* *}$ & .11 & $-.22^{*}$ & $.28^{* *}$ & - & $.52^{* *}$ \\
& Stress & -.13 & .03 & .00 & .12 & $.52^{* *}$ & - \\
\hline
\end{tabular}

Note: $* *$ means correlation is significant at the 0.01 level, ${ }^{*}$ means correlation is significant at the 0.05 level.

Table 5. Means and standard deviations of self-efficacy and burnout per cluster.

\begin{tabular}{|c|c|c|c|c|c|c|c|c|}
\hline & \multirow{2}{*}{\multicolumn{2}{|c|}{$\begin{array}{l}\text { Self-efficacy } \\
\text { (5-point Likert } \\
\text { scale) }\end{array}$}} & \multicolumn{6}{|c|}{ Burnout } \\
\hline & & & \multicolumn{2}{|c|}{$\begin{array}{c}\text { Inadequacy } \\
\text { (5-point Likert scale) }\end{array}$} & \multicolumn{2}{|c|}{$\begin{array}{c}\text { Exhaustion } \\
\text { (7-point Likert scale) }\end{array}$} & \multicolumn{2}{|c|}{$\begin{array}{c}\text { Stress } \\
(10 \text {-point Likert scale })\end{array}$} \\
\hline & $\mathrm{M}$ & SD & $\mathrm{M}$ & SD & $\mathrm{M}$ & $\mathrm{SD}$ & $\mathrm{M}$ & SD \\
\hline Cluster 1 & 3.74 & .90 & 1.66 & .61 & 3.54 & 1.74 & 5.52 & 2.77 \\
\hline Cluster 2 & 4.40 & .58 & 2.22 & 1.13 & 3.25 & 1.75 & 5.14 & 2.96 \\
\hline Cluster 3 & 4.44 & .56 & 1.61 & .71 & 2.67 & 1.37 & 4.68 & 2.72 \\
\hline
\end{tabular}

Note: Cluster 1: Teacher educators with a vague approach; Cluster 2: Teacher educators with a dissonant approach; Cluster 3: Teacher educators with a student-focused approach.

Table 6. Post hoc tests of self-efficacy and inadequacy in teacher-student interaction of the three clusters.

\begin{tabular}{lcccc}
\hline & Self-efficacy & \multicolumn{2}{c}{ Inadequacy } \\
& Mean difference & $p$ & Mean difference & $p$ \\
\hline Cluster 1 - Cluster 2 & -.66 & .007 & -.56 & .042 \\
Cluster 1 - Cluster 3 & -.70 & .003 & .05 & .986 \\
Cluster 2 - Cluster 3 & -.04 & .976 & .61 & .016 \\
\hline
\end{tabular}

Note: Cluster 1: Teacher educators with a vague approach; Cluster 2: Teacher educators with a dissonant approach; Cluster 3: Teacher educators with a student-focused approach. 
Table 7. Standardised coefficients of predictor variables on CCSF scale.

\begin{tabular}{lccc}
\hline Variable & $\begin{array}{c}\text { Standardised } \\
\text { coefficients (Beta) }\end{array}$ & $\mathrm{t}$ & $p$ \\
\hline Constant & & 3.07 & .003 \\
Self-efficacy & .64 & 8.16 & $<.001$ \\
Inadequacy & .25 & 3.20 & .002 \\
Exhaustion & -.16 & -1.77 & .080 \\
Stress & -.06 & -.66 & .513 \\
\hline
\end{tabular}

Table 8. Standardised coefficients of predictor variables on ITTF scale.

\begin{tabular}{lccc}
\hline Variable & $\begin{array}{c}\text { Standardised } \\
\text { coefficients (Beta) }\end{array}$ & $\mathrm{t}$ & $p$ \\
\hline Constant & & 2.96 & .004 \\
Self-efficacy & .11 & 1.17 & .245 \\
Inadequacy & .40 & 4.19 & $<.001$ \\
Exhaustion & .06 & .56 & .580 \\
Stress & -.05 & -.50 & .618 \\
\hline
\end{tabular}




\section{FIGURES}

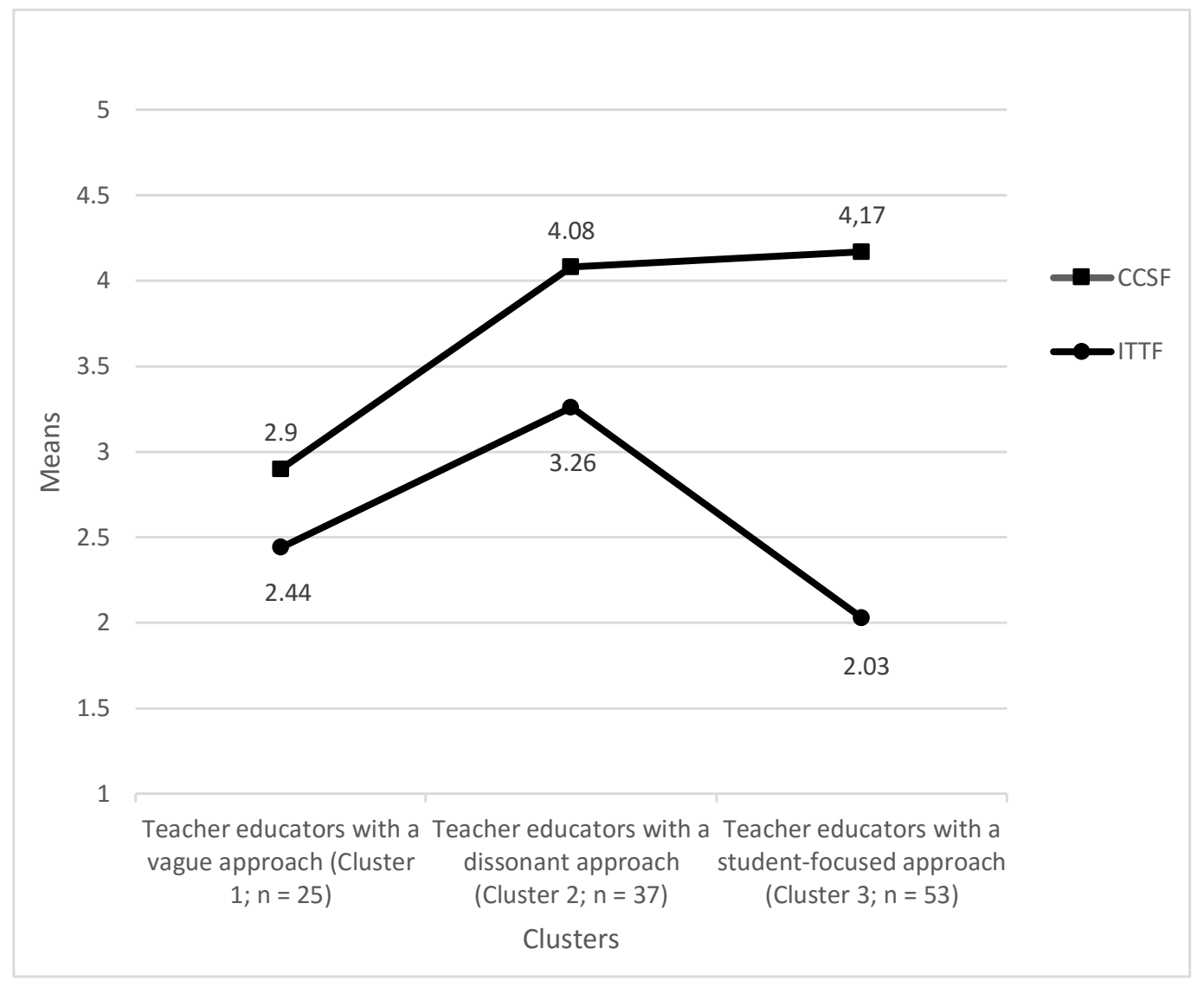

Figure 1. Means of three clusters on CCSF and ITTF scales of approaches to teaching (Cao et al. forthcoming). 




Figure 2. Means of three clusters' self-efficacy and burnout. 